\title{
Pengaruh Pendidikan Kesehatan terhadap Pengetahuan Wus Tentang Flour Albus di BPM Dewi Suyanti Tahun 2020
}

\author{
Saddiyah Rangkuti \\ Program Studi Kebidanan, Universitas Haji Sumatera Utara
}

\begin{tabular}{|c|c|}
\hline Info Artikel & A B S T RA K \\
\hline $\begin{array}{l}\text { Article history: } \\
\text { Diterima 08-06-2021 } \\
\text { Revisi 22-06-2021 } \\
\text { Disetujui 09-07-2021 }\end{array}$ & $\begin{array}{l}\text { Masalah kesuburan alat reproduksi merupakan hal yang sangat penting untuk } \\
\text { diketahui oleh wanita usia subur (WUS), kadar estrogen wanita sering relatif } \\
\text { stabil atau bahkan meningkat, dan aktifitas wanita usia subur lebih aktif } \\
\text { daripada wanita yang tidak dalam masa subur, tujuan penelitian untuk } \\
\text { mempelajari pengaruh pengaruh pendidikan kesehatan terhadap pengetahuan }\end{array}$ \\
\hline Kata kunci: & $\begin{array}{l}\text { menggunakan jenis penelitian Pre-eksperimental, dengan desain One Group } \\
\text { pre-test and post-test design, Populasi dalam penelitian adalah seluruh wanita }\end{array}$ \\
\hline $\begin{array}{l}\text { Pendidikan Kesehatan, } \\
\text { Pengetahuan, } \\
\text { Flour albus. }\end{array}$ & $\begin{array}{l}\text { usia subur yang yang berkunjung ke BPM Dewi Suyanti data yang } \\
\text { dikumpulkan bulan januari - juni sebanyak } 30 \text { wanita usia subur yang } \\
\text { berkunjung keperaktek bidan Dewi Suyanti, sampel dalam penelitian ini } \\
\text { Teknik Purposive Sampling, dengan teknik penelitian menggunakan uji Chi } \\
\text { Kuadrat. Hasil penelitian ini Ada pengaruh yang signifikan pengetahuan WUS } \\
\text { tentang flour albus sebelum diberikan pendidikan kesehatan di BPM Dewi } \\
\text { Suyanti Tahun } 2020 \text { mayoritas kurang yaitu sebanyak } 6 \text { responden }(60,0 \%) \text {, } \\
\text { pengetahuan WUS tentang flour albus sesudah diberikan pendidikan } \\
\text { kesehatan di BPM Dewi Suyanti Tahun } 2020 \text { mayoritas baik yaitu sebanyak } 5 \\
\text { responden (50,0\%), pengaruh yang signifikan pendidikan kesehatan terhadap } \\
\text { pengetahuan WUS tentang flour albus di BPM Dewi Suyanti Tahun } 2020 \text {. } \\
\text { Disarankan Petugas Kesehatan khususnya bidan sebaiknya memasukkan } \\
\text { materi hygiene genitalia dalam pendidikan kesehatan dan program rutin untuk } \\
\text { WUS dengan memanfaatkan program yang sudah ada seperti penyuluhan ke } \\
\text { sekolah-sekolah, pemeriksaan IVA, kelas ibu hamil dan kelas ibu bayi/balita. }\end{array}$ \\
\hline
\end{tabular}

\section{Koresponden Penulis:}

Saddiyah Rangkuti,

Program Studi Kebidanan, Universitas Haji Sumatera Utara,

J1. Rumah Sakit H., Medan Estate, Kec. Percut Sei Tuan, Kabupaten Deli Serdang, Sumatera Utara 20371.

Email: saddiyahrangkuti76@gmail.com

\section{PENDAHULUAN}

Kesehatan reproduksi menurut World Health Organization (WHO) adalah kesejahteraan fisik, mental, dan sosial yang utuh dan bukan hanya tidak adanya penyakit atau kelemahan dalam segala hal yang berhubungan dengan sistem reproduksi dan fungsi-fungsinya serta proses-prosesnya. Kesehatan reproduksi di kalangan wanita harus memperoleh perhatian yang serius, salah satunya adalah keputihan. Vagina dilindungi terhadap infeksi oleh PH-nya yang normalnya rendah (3,5 4.5), yang dipertahankan oleh aksi basil Doderlain's (bagian dari flora normal vagina) dan hormon estrogen. Risiko infeksi meningkat jika daya tahan tubuh wanita diturunkan oleh stres atau penyakit, PH terganggu, atau jumlah organisme yang masuk meningkat (Sulistianingsih, 2017).

Keputihan sebagai gejala yang sangat sering dialami oleh sebagian besar wanita. Gangguan ini merupakan masalah kedua sesudah gangguan haid. Keputihan seringkali tidak ditangani dengan serius. Padahal, keputihan bisa jadi indikasi adanya penyakit. Menurut Manuaba (2003) dalam Setyana (2016), keputihan adalah semua cairan dari genitalia yang bukan darah. Keputihan (leukorea) merupakan gejala umum dari hampir semua penyakit kandungan. Leukorea bukanlah 
penyakit tersendiri melainkan manifestasi klinis dari berbagai penyakit. Keputihan dapat menjadi manifestasi dari sebuah penyakit organ reproduksi. Salah satunya adalah sebagai manifestasi dari adanya kanker serviks (kanker leher rahim). Dimana keputihan yang ditimbulkan oleh akibat adanya kanker ini adalah berwarna putih sampai purulen yang berbau dan terasa gatal, terjadinya perdarahan pasca koitus, perdarahan spontan, dan bau busuk yang khas (Setyana, 2016).

Ada dua hal yang menjadi faktor pendorong keputihan yaitu faktor endogen dari dalam tubuh dan faktor eksogen dari luar tubuh, yang keduanya saling mempengaruhi. Faktor endogen yaitu kelainan pada lubang kemaluan, faktor eksogen di bedakan menjadi dua yakni karena infeksi dan non infeksi. Faktor infeksi yaitu bakteri, jamur, parasit, virus, sedangkan faktor non infeksi adalah masuknya benda asing ke vagina baik sengaja maupun tidak, cebok tidak bersih, daerah sekitar kemaluan lembab, kondisi tubuh, kelainan endokrin atau hormone, menopause (Indriyani, 2017).

Fluor albus/leukorea/cairan putih adalah satu bentuk cairan vagina dan/atau serviks pada wanita. Keluhan dapat diserta dengan gatal, disuria, dan nyeri abdominal bawah atau nyeri punggung bawah (LBP). Dalam kondisi normal, terlihat cairan vaginal yang jernih, putih berkabut atau kekuningan ketika kering pada pakaian (Sholikah R, 2016).

World Health Organization (WHO) dalam Suryandari dan Rufaida (2016) menyebutkan bahwa hampir seluruh wanita dan remaja putri pernah mengalami keputihan, 60\% pada remaja (1522 tahun) dan 40\% pada wanita (23-45 tahun), Jika dibiarkan keputihan dapat menyebabkan dampak yang buruk bagi kesehatan, salah satunya adalah kanker serviks. Sedangkan menurut Wulandari (2015) wanita yang pernah mengalami keputihan, sebanyak 75\% mengalami keputihan minimal 1 kali dalam seumur hidupnya dengan $50 \%$ pada remaja dan $25 \%$ pada wanita usia subur (WUS) dari 95\% kasus kanker leher rahim yang terjadi pada wanita di Indonesia ditandai dengan keputihan (Suryandari DF, 2016).

Keputihan dapat berupa fisiologis (normal) dan patologis (tidak normal). Dalam keadaan normal, vagina akan menghasilkan cairan yang tidak berwarna (bening), tidak berbau, dan dalam jumlahnya tidak terlalu banyak, tanpa rasa panas atau nyeri. Sedangkan keputihan tidak normal akan sebaliknya, biasanya berwarna kuning, hijau atau keabu-abuan, berbau amis atau busuk, jumlahnya banyak dan di sertai gatal dan rasa panas atau nyeri pada daerah vagina (Nanlessy, 2016). Banyak wanita mengeluhkan tentang keputihan yang tidak nyaman, gatal, berbau, bahkan terkadang perih. Keputihan fisiologis tidak berdampak apapun bagi wanita, keputihan yang member dampak adalah yang patologis. Dengan adanya keputihan yang patologis tersebut wanita merasa tidak nyaman karena menunjukkan keluhan berbau busuk, gatal, vulva terasa seperti terbakar. Apabila keputihan tidak diobati, maka infeksi dapat menjalar ke rongga rahim kemudian sampai ke indung telur dan akhirnya sampai ke rongga panggul. Banyak wanita yang ditemukan menderita keputihan kronik menjadi mandul. Tidak hanya bisa mengakibatkan kemandulan dan hamil di luar kandungan dikarenakan terjadi penyumbatan pada saluran tuba, keputihan juga bisa merupakan gejala awal dari kanker leher rahim yang merupakan pembunuh nomor satu bagi wanita dengan angka insiden kanker serviks diperkirakan mencapai 100 per 100.000 penduduk pertahun, yang bisa berujung pada kematian (Setyana, 2016).

Berdasarkan data WHO (2007), angka prevalensi tahun 2006, 25\%-50\% candidiasis, 20\%$40 \%$ bacterial vaginosis dan 5\%-15\% trichomoniasis. Wanita di Eropa yang mengalami keputihan sekitar 25\%. Di Indonesia sebanyak $75 \%$ wanita pernah mengalami keputihan minimal satu kali dalam hidupnya dan $45 \%$ diantaranya bisa mengalami keputihan sebanyak dua kali atau lebih (Nanlessy, 2016).

Untuk mencegah terjadinya keputihan berulang, maka wanita harus selalu menjaga kebersihan alat kelamin luarnya. Sebaiknya jangan terlalu sering melakukan douche (mencuci/membilas) vagina dengan larutan antiseptik dapat merugikan, karena akan menghilangkan cairan vagina yang normal dan dapat mematikan bakteri alamiah di dalam vagina. Untuk itu dianjurkan hanya mencuci alat kelamin bagian luar dengan air bersih dan sabun mandi saja (Setyana, 2016). Berdasarkan hasil penelitian yang dilakukan oleh Kumalasari menyebutkan bahwa tahun 2002, 50\% wanita Indonesia pernah mengalami keputihan, kemudian pada tahun 2003, 60\% wanita pernah mengalami keputihan, sedangkan tahun 2004 hampir $70 \%$ wanita Indonesia pernah mengalami keputihan setidaknya sekali dalam hidupnya (Melati, 2017). 
Banyak wanita di Indonesia yang tidak tahu tentang keputihan sehingga mereka menggangap keputihan sebagai hal yang umum dan sepele, di samping itu rasa malu ketika mengalami keputihan kerap membuat wanita enggan berkonsultasi ke dokter. Padahal keputihan tidak bisa di anggap sepele, karena akibat dari keputihan ini sangat fatal bila lambat di tangani tidak hanya bisa mengakibatkan kemandulan dan hamil di luar kandungan, keputihan juga bisa merupakan gejala awal dari kanker leher yang bisa berujung pada kematian (Indriyani, 2017). Keputihan juga dapat menekan kejiwaan seseorang karena keputihan cenderung kambuh dan timbul kembali sehingga dapat mempengaruhi seseorang baik secara fisiologi maupun psikologis (Solikhah, 2016).

Keputihan bila tidak diatasi dapat menimbulkan masalah kesehatan yang lebih serius seperti infertilitas / masalah kesuburan, penyakit radang panggul (Pelvic Inflammatory Disease). Pada wanita hamil, infeksi trikomonas dan bacterial vaginosis diduga dapat menyebabkan kelahiran prematur dan berat badan lahir rendah (BBLR) (Medika Holistik, 2008). Wanita yang tinggal di pedesaan mengalami gejala keputihan lebih banyak akibat belum baiknya perilaku sehat dalam pencegahan keputihan patologis (Badaryati, 2017). Ada beberapa faktor penghambat dalam berperilaku sehat dalam upaya pencegahan keputihan patologis, diantaranya adalah kurangnya pengetahuan dan kesadaran individu tentang keputihan dan pencegahannya, dan minimnya pelayanan kesehatan yang ada di daerah pedesaan. (Badaryati, 2017)

Sumatera Utara khususnya Kelurahan Bagan Deli. Kelurahan Bagan Deli merupakan salah satu dari 6 (enam) kelurahan yang ada di Kecamatan Belawan yang merupakan kantong penduduk miskin di Kota Medan. Jumlah penduduk di Kelurahan Bagan Deli adalah 15.860 jiwa, dan yang berada di bawah garis kemiskinan ada 8.635 jiwa atau 54,45\% (BPS Provinsi Sumatera Utara, 2019).

Merawat kebersihan organ seksual seringkali tidak dilakukan sesering merawat kebersihan organ tubuh lainnya. Padahal organ seksual membutuhkan perhatian yang ekstra. Pada organ seksual tersebut keringat yang dihasilkan cukup berlebih. Sehingga organ seksual tersebut menjadi lebih lembab yang dapat menjadi media berkembangbiaknya bakteri, penyakit dan bau tidak sedap. Setiap tahun, sekitar 100 juta wanita di seluruh dunia terkena infeksi genital termasuk infeksi saluran kemih dan vaginosis bakteri, dan $75,0 \%$ wanita memiliki riwayat infeksi genital. Studi yang melibatkan berbagai tingkat masyarakat melaporkan prevalensi keputihan abnormal dari $12,1 \%$ menjadi $30 \%$. Infeksi saluran kelamin wanita dapat menyebabkan vaginitis, servisitis, dan uretritis, dan trikomoniasis telah dikaitkan dengan hasil kehamilan yang buruk (Hamed AG, 2015).

Masalah kesuburan alat reproduksi merupakan hal yang sangat penting untuk diketahui oleh wanita usia subur (WUS), kadar estrogen wanita sering relatif stabil atau bahkan meningkat, dan aktifitas wanita usia subur lebih aktif daripada wanita yang tidak dalam masa subur. Wanita dalam masa subur harus menjaga dan merawat personal hygiene yaitu pemeliharaan keadaan alat kelaminnya dengan rajin membersihkannya, apabila hal ini tidak diperhatikan dapat menyebabkan terjadinya fluor albus (Sukartia, 2003). Keputihan biasa dianggap sepele, padahal keputihan bisa menjadi sangat fatal bila terlambat ditangani, keputihan juga dapat menjadi gejala awal dari ca serviks yang bisa berujung pada kematian (Indriyani, 2017)

Masalah reproduksi perlu mendapat penanganan serius, karena masalah tersebut paling banyak muncul pada negara berkembang, seperti Indonesia karena kurang tersedianya akses untuk mendapat informasi mengenai kesehatan reproduksi. Seseorang yang tidak memiliki pemahaman tentang kesehatan reproduksi akan cenderung mengabaikan kesehatan reproduksi dan pada akhirnya ia akan memiliki tindakan yang membahayakan bagi dirinya sendiri. Akibat kurangnya pemahaman personal hygiene genitalia pada wanita yaitu terjadinya gangguan kesehatan organ reproduksi seperti keputihan, infeksi saluran kemih (ISK), penyakit radang panggul (PRP) dan kemungkinan terjadi kanker leher rahim. Untuk itu, wanita perlu dididik tentang praktik higienis genital agar terhindar dari bahaya perilaku buruk dan mengurangi tingkat infeksi vagina (Sandriana, Indra Fajarwati Ibnu, Watief A. Rachman, 2014)

Berdasarkan penelitian Irmayani tahun 2018 "pengaruh pendidikan kesehatan terhadap pengetahuan dan sikap hygiene genital wanita usia subur" hasil uji Paired Sample T Test diperoleh nilai significacy $0,000(\mathrm{p}<0,05)$ artinya terdapat perbedaan rerata sikap yang bermakna sebelum dan sesudah pendidikan kesehatan. Nilai CI 95\% adalah antara 2,13 - 5,91. meningkat rata-rata dari 11

JURKESMAS : Jurnal Kesehatan Masyarakat, Vol. 1, No. 1, Juli 2021: 14 - 21 
menjadi 13.Hasil uji statistik menunjukkan adanya pengaruh yang signifikan pendidikan kesehatan terhadap pengetahuan hygiene genital pada WUS.

Penelitian yang dilakukan oleh Roselina Panghiyangani tahun 2018 "efektivitas metode penyuluhan kesehatan terhadap peningkatan pengetahuan, sikap dan tindakan tentang pencegahan keputihan patalogis" dengan hasil analisis data dengan regresi logistic. Responden kontrol menunjukkan tidak terdapat perbedaan antara sebelum dan sesudah dilakukan penyuluhan $\mathrm{p}$-value $(0,176)$. Berbeda dengan hasil analisis dari responden perlakukan yang menunjukkan terdapat hubungan antara sebelum dan sesudah dilakukan penyuluhan p-value $(0,000)$. Kesimpulan dari penelitian ini tidak terdapat hubungan pengetahuan pada responden control dan terdapat hubungan pada responden perlakukan dengan peningkatan pengetahuan, sikap dan tindakan tentang pencegahan keputihan patalogis.

Berdasarkan survey awal yang dilakukan pada tanggal 28 April 2020 melalui wawancara, didapatkan data bahwa banyak wanita usia subur yang mengalami flour albus, sehingga diperlukan pendidikan kesehatan.

\section{METODE PENELITIAN}

Penelitian ini dilakukan di BPM Dewi Suyanti. Wilayah Dewi Suyanti. BPM Dewi Suyanti merupakan bentuk pelayanan kesehatan dibidang kesehatan dasar sesuai dengan kewenangan dan kemampuan bidan. BPM Dewi Suyanti memberikan pelayanan selama 24 jam untuk masyarakat, dan memiliki tempat dan ruangan praktek yang memenuhi persyaratan kesehatan, mempunyai tempat tidur untuk persalinan dan memiliki 5 tempat tidur, memiliki peralatan yang sesuai dengan ketentuan dan menyediakan obat-obatan sesuai dengan ketentuan yang berlaku

\section{HASIL DAN PEMBAHASAN}

\subsection{Hasil}

\section{Analisa Univariat}

Karakteristik responden di BPM Dewi Suyanti Tahun 2020 pada penelitian ini dikelompokkan berdasarkan umur, pendidikan, dan pekerjaan. Karakteristik resonden diuraikan dalam tabel 1 di bawah sebagai berikut:

Tabel 1. Karakteristik Responden di BPM Dewi Suyanti Tahun 2020

\begin{tabular}{|c|c|c|c|}
\hline No & Data Demografi & Frekuensi & Presentase (\%) \\
\hline \multirow[t]{4}{*}{1} & Umur & & \\
\hline & 20-28 tahun & 6 & 60,0 \\
\hline & 29-35 tahun & 4 & 40,0 \\
\hline & Jumlah & 10 & 100 \\
\hline \multirow[t]{4}{*}{2} & Pendidikan & & \\
\hline & SMA & 8 & 80,0 \\
\hline & D-III/ S-1 & 2 & 20,0 \\
\hline & Jumlah & 10 & 100 \\
\hline \multirow[t]{4}{*}{$\mathbf{3}$} & Pekerjaan & & \\
\hline & Bekerja & 4 & 40,0 \\
\hline & Tidak Bekerja & 6 & 60,0 \\
\hline & Jumlah & 10 & 100 \\
\hline
\end{tabular}

Berdasarkan tabel 1 di atas sebagian besar responden mayoritas berusia antara 20-28 tahun yaitu 6 responden $(60,0 \%)$ dengan tingkat pendidikan mayoritas SMA yaitu 8 responden $(80 \%)$. Dilihat dari pekerjaan, sebagian besar responden tidak bekerja sebanyak 6 responden $(60,0 \%)$.

Data pengetahuan WUS tentang flour albus sebelum diberikan pendidikan kesehatan di BPM Dewi Suyanti Tahun 2020 dapat dilihat pada tabel 2 di bawah berikut :

Tabel 2. Pengetahuan WUS Tentang Flour Albus Sebelum Diberikan Pendidikan Kesehatan di BPM Dewi Suyanti Tahun 2020

\begin{tabular}{ccc}
\hline Pengetahuan WUS Tentang Flour Albus (Pre tes) & Frekuensi & $\%$ \\
\hline Baik & 0 & 0,0 \\
Cukup & 4 & 40,0 \\
Kurang & 6 & 60,0
\end{tabular}


Berdasarkan tabel 2 di atas menunjukkan bahwa pengetahuan WUS tentang flour albus sebelum diberikan pendidikan kesehatan di BPM Dewi Suyanti Tahun 2020 mayoritas kurang yaitu sebanyak 6 responden $(60,0 \%)$.

Data pengetahuan WUS tentang flour albus sesudah diberikan pendidikan kesehatan di BPM Dewi Suyanti Tahun 2020 dapat dilihat pada tabel 3 di bawah berikut :

Tabel 3. Pengetahuan WUS Tentang Flour Albus Sesudah Diberikan Pendidikan Kesehatan di BPM Dewi Suyanti Tahun 2020

\begin{tabular}{ccc}
\hline Pengetahuan WUS Tentang Flour Albus (Post tes) & Frekuensi & \% \\
\hline Baik & 5 & 50,0 \\
Cukup & 4 & 40,0 \\
Kurang & 1 & 10,0 \\
\hline Jumlah & 10 & 100 \\
\hline
\end{tabular}

Berdasarkan tabel 3 di atas menunjukkan bahwa pengetahuan WUS tentang flour albus sesudah diberikan pendidikan kesehatan di BPM Dewi Suyanti Tahun 2020 mayoritas baik yaitu sebanyak 5 responden $(50,0 \%)$.

Hasil uji statistik pengaruh pendidikan kesehatan terhadap pengetahuan WUS tentang flour albus di BPM Dewi Suyanti Tahun 2020 terdapat pada tabel 4 di bawah sebagai berikut :

Tabel 4. Pengaruh Pendidikan Kesehatan Terhadap Pengetahuan WUS Tentang Flour Albus di BPM Dewi Suyanti Tahun 2020

\begin{tabular}{lcclcc}
\hline \multirow{2}{*}{$\begin{array}{l}\text { Pengetahuan WUS } \\
\text { Tentang Flour Albus }\end{array}$} & \multicolumn{2}{c}{ Perlakuan } & \multirow{2}{*}{ Perubahan Ranking } & \multirow{2}{*}{ p value } \\
\cline { 2 - 3 } & Sebelum & Sesudah & & f \\
\hline - Baik & 0 & 5 & Rangking Positif & 0 & $0,000^{*}$ \\
- Cukup & 4 & 4 & Rangking Negatif & 9 & \\
- Kurang & 6 & 1 & Ties & 1 & \\
\hline
\end{tabular}

Keterangan : a) Uji Wilcoxon

Perubahan Pengetahuan WUS tentang flour albus:

a. Ranking Negatif adalah perubahan pengetahuan sebelum dan sesudah dari kategori 'kurang' menjadi kategori 'cukup dan baik"

b. Ranking Positif adalah perubahan sebelum dan sesudah dari kategori 'baik' menjadi 'cukup' atau 'kurang'

c. Ties artinya tidak terjadi perubahan pengetahuan sebelum dan sesudah

Berdasarkan tabel 4 di atas menunjukan pengetahuan WUS tentang flour albus sebelum dan sesudah diberikan pendidikan kesehatan mengalami perubahan. Pengetahuan WUS tentang flour albus sebelum diberikan pendidikan kesehatan sebanyak 6 responden masuk dalam kategori kurang dan menjadi 1 responden sesudah diberikan pendidikan kesehatan. Sedangkan pengetahuan WUS tentang flour albus sebelum diberikan pendidikan kesehatan tidak ada yang masuk dalam kategori baik dan setelah diberikan pendidikan kesehatan, pengetahuan WUS bertambah menjadi 5 responden.

Berdasarkan Hasil uji statistic dengan menggunakan Uji Wilcoxon diketahui bahwa nilai $\mathrm{p}$ $(0,004)<\alpha(0,05)$ artinya Ho ditolak, jadi terdapat pengaruh yang signifikan pendidikan kesehatan terhadap pengetahuan WUS tentang flour albus di BPM Dewi Suyanti Tahun 2020. Hasil ini membuktikan bahwa pendidikan kesehatan dapat memberikan pengaruh yang baik terhadap peningkatan pengetahuan WUS tentang flour albus di BPM Dewi Suyanti Tahun 2020.

\subsection{Pembahasan}

Berdasarkan tabel 4.2 menunjukkan bahwa pengetahuan WUS tentang flour albus sebelum diberikan pendidikan kesehatan di BPM Dewi Suyanti Tahun 2020 mayoritas kurang yaitu sebanyak 6 responden $(60,0 \%)$. Responden tersebut memiliki pengetahuan yang kurang disebabkan karena sebagian besar menjawab tidak tahu dalam menjawab kuesioner tentang flour albus (keputihan).

Kurangnya pengetahuan wanita usia subur tentang flour albus dikarenakan minimnya fasilitas pelayanan, konseling dan penyuluhan tentang flour albus kepada wanita usia subur, penguasaan materi yang kurang dari petugas kesehatan dan metode penyampaian yang kurang tepat sehingga tujuan penyuluhan tidak tercapai. 
Faktor-faktor yang mempengaruhi pengetahuan antara lain, pendidikan. Dalam penelitian ini pendidikan wanita usia subur adalah berpendidikan tingkat menengah atau SMA, sehingga pengetahuan tentang flour albus seharusnya sudah baik. Akan tetapi kemungkinan pengetahuan tentang flour albus tidak didapat di sekolah pendidikan formal sehingga mereka kurang memahami tentang flour albus atau keputihan. Sehingga menurut peneliti berdasarkan karakteristik responden, sangat mempengaruhi nilai yang didapat sebelum penyuluhan dimana sebagian besar memang belum mengetahui sepenuhnya tentang flour albus.

Sejalan dengan teori Notoadmotjo (2012) sebagian besar pengetahuan manusia diperoleh melalui mata dan telinga (Notoatmodjo, 2003). Pengetahuan itu sendiri dipengaruhi oleh faktor pendidikan formal. Tetapi tidak berarti seseorang yang berpendidikan rendah mutlak berpengetahuan rendah pula. Mengingat peningkatan pengetahuan tidak mutlak diperoleh dari pendidikan formal saja, tetapi dapat diperoleh melalui pendidikan non formal. Pengetahuan seseorang tentang suatu objek mengandung dua aspek yaitu aspek positif dan aspek negatif. Kedua aspek ini yang akan menentukan sikap dan pengetahuan seseorang, semakin banyak aspek positif dan objek yang diketahui, maka akan menimbulkan sikap makin positif terhadap objek tertentu.

Asummi penelitian mengenai tingkat pengetahuan wanita usia subur tentang flour albus atau keputihan di BPM Dewi Suyanti didapatkan hasil bahwa sebagian besar WUS memiliki pengetahuan yang kurang tentang keputihan. Perlu adanya upaya peningkatan pengetahuan WUS tentang keputihan dan personal higiene khususnya alat genital yaitu dengan memberikan konseling sehingga kejadian keputihan pada wanita usia subur dapat berkurang.

Berdasarkan hasil penelitian menunjukkan bahwa pengetahuan WUS tentang flour albus sesudah diberikan pendidikan kesehatan di BPM Dewi Suyanti Tahun 2020 mayoritas baik yaitu sebanyak 5 responden $(50,0 \%)$.

Keberhasilan suatu penyuluhan kesehatan dapat dipengaruhi oleh faktor penyuluh, sasaran dan proses penyuluh. Penyuluhan kesehatan adalah kegiatan pendidikan kesehatan, yang dilakukan dengan menyebarkan pesan, menanamkan keyakinan, sehingga masyarakat tidak saja sadar, tahu dan mengerti, tetapi juga mau dan bisa melakukan suatu anjuran yang ada hubungannya dengan kesehatan. Tujuan dalam penyuluhan tentang flour albus tersebut diharapkan wanita usia subur lebih mengetahui tentang flour albus dan dapat menyikapi kondisi dengan bijak sehingga siap dalam mencegah keputihan dan menjaga kebersihan vulva hygiene. (Irmayani, 2018)

Berdasarkan hasil penelitian diketahui bahwa terjadi peningkatan pengetahuan pada semua responden yang mengikuti penyuluhan, walaupun peningkatan tersebut tidak merata karena ada yang mengalami peningkatan, hal ini mungkin disebabkan oleh berbagai hal seperti disaat penelitian atau penyuluhan berlangsung, ada responden yang dengan baik menyimak setiap kata yang disampaikan oleh penyuluh dalam hal ini peneliti dan ada responden yang tidak begitu konsentrasi pada saat penyuluhan dan ini pun menjadi keterbatasan dalam penelitian dimana peneliti tidak dapat mengintervensi seluruh peserta penyuluhan.

Pengetahuan itu sendiri dipengaruhi oleh faktor pendidikan formal. Pengetahuan sangat erat hubungannya dengan pendidikan, dimana diharapkan bahwa dengan pendidikan yang tinggi maka orang tersebut akan semakin luas pula pengetahuannya. Akan tetapi perlu ditekankan, bukan berarti seseorang yang berpendidikan rendah mutlak berpengetahuan rendah pula. Pengetahuan seseorang tentang suatu objek mengandung dua aspek, yaitu aspek positif dan negatif. Kedua aspek ini yang akan menentukan sikap seseorang semakin banyak aspek positif dan objek yang diketahui, maka akan menimbulkan sikap makin positif terhadap objek tertentu (Estiani \& Dhuhana, 2015).

Berdasarkan hasil analisis di atas penulis pengetahuan dapat dipengaruhi dari berbagai faktor tidak hanya dari informasi yang didapat selama penyuluhan namun juga ada faktor lain seperti lingkungan dan lain-lain sehingga dari tingkat pengetahuan ini terdapat beberapa perbedaan kondisi masyarakat dan kepercayaan masyarakat terhadap kesehatan, yang pada akhirnya mengubah sikap wanita usia suburtentang flour albus, tingginya arus informasi yang diterima masyarakat setempat, rendahnya tingkat pengetahuan masyarakat mengenai flour albus disebabkan oleh kurangnya informasi mengenai apa itu flour albus, cara mencegah, cara menjaga kebersihan organ genetalia, sehingga jika tidak mengetahui maka akan menimbulkan keputihan yang berlebihan, terasa gatal dan berbau.(Irmayani, 2018). 
Hal ini sesuai pendapat Rini (2015), tujuan dari vulva higiene sendiri adalah untuk menjaga organ genetalia khususnya organ genetalia wanita supaya tetap bersih, sehat, tidak lembab supaya bakteri tidak mudah masuk dan mengakibatkan bau yang tidak sedap sehingga menimbulkan keputihan yang berlebihan, terasa gatal dan berbau.

Berdasarkan hasil analisis data menunjukan pengetahuan WUS tentang flour albus sebelum dan sesudah diberikan pendidikan kesehatan mengalami perubahan. Pengetahuan WUS tentang flour albus sebelum diberikan pendidikan kesehatan sebanyak 6 responden masuk dalam kategori kurang dan menjadi 1 responden sesudah diberikan pendidikan kesehatan. Sedangkan pengetahuan WUS tentang flour albus sebelum diberikan pendidikan kesehatan tidak ada yang masuk dalam kategori baik dan setelah diberikan pendidikan kesehatan, pengetahuan WUS bertambah menjadi 5 responden.

Berdasarkan Hasil uji statistic dengan menggunakan Uji Wilcoxon diketahui bahwa nilai $p$ $(0,004)<\alpha(0,05)$ artinya Ho ditolak, jadi terdapat pengaruh yang signifikan pendidikan kesehatan terhadap pengetahuan WUS tentang flour albus di BPM Dewi Suyanti Tahun 2020. Hasil ini membuktikan bahwa pendidikan kesehatan dapat memberikan pengaruh yang baik terhadap peningkatan pengetahuan WUS tentang flour albus di BPM Dewi Suyanti Tahun 2020.

Berdasarkan hasil tersebut sebagian besar responden memiliki pengetahuan baik setelah diberikan pendidikan kesehatan. Adanya peningkatan pengetahuan responden mengenai flour albus sebagai akibat dari penerimaan informasi baru melalui pendidikan kesehtan yang dapat dipahami dengan baik oleh wanita usia subur. Menurut Setiawati dan Dermawan (2012) pendidikan kesehatan merupakan suatu upaya yang dilalukan untuk mempengaruhi seseorang yaitu baik dari individu, kelompok, keluarga maupun masyarakat agar terlaksana perilaku hidup yang sehat serta memiliki tujuan untuk meningkatkan pengetahuan.

Pendidikan kesehatan dengan metode ceramah dapat meningkatkan pengetahuan seseorang dimana metode ini paling mudah diterapkan dalam masyarakat dengan pengetahuan yang berbedabeda. Adapun keunggulan dari metode ceramah ini adalah seperti pemberi ceramah mudah dalam menguasai pertemuan tersebut, dapat diikuti oleh banyak orang, relatif mudah dalam penyiapan dan pelaksanaan. Teknik ceramah yang baik mendukung tercapainya penyerapan dan pemahaman optimal sehingga menambah pengetahuan seseorang (Azizah, 2015).

Hal ini dikarenakan pemberian pendidikan kesehatan dilakukan dengan menggunakan metode ceramah disertai demonstrasi dan media leaflet, sehingga segala pesan atau informasi yang disampaikan dapat diterima dengan baik dan jelas oleh pendengar. Dengan demikian, untuk meningkatkan pengetahuan WUS maka pendidikan kesehatan tentang flour albus sangat diperlukan agar terjadi perubahan sikap yang positif dalam perilaku pencegahan keputihan. Perilaku akan bersifat langgeng apabila didasari oleh pengetahuan dan kesadaran sikap yang positif. Hal ini sejalan dengan tujuan dari dilakukannya penyuluhan kesehatan yakni peningkatan pengetahuan masyarakat di bidang kesehatan, tercapainya perubahan perilaku, individu, keluarga, dan masyarakat sebagai sasaran utama penyuluhan kesehatan dalam membina perilaku sehat dan lingkungan sehat serta berperan aktif dalam upaya meningkatkan derajat kesehatan yangoptimal sesuai dengan konsep sehat sehingga dapat menurunkan angka kesakitan dan kematian (Notoatmodjo, 2012).

Hasil penelitian ini mendukung penelitian Irmayani (2018) yang membuktikan bahwa pendidikan kesehatan tentang hygiene genital cukup efektif dan efisien serta memberikan pengaruh untukmeningkatkan pengetahuan WUS dalam jangka waktu yang singkat dan sesuai teori yang sudah ada, selain itu pengemasan materi yang menarik, cara penyampaian materi dan bahasa penyampain yang disesuaikan dengan tingkat pendidikan, umur responden berpengaruh terhadap peningkatan pengetahuan responden.Menurut Notoatdmojo (2012), tingkat pengetahuan seseorang dipengaruhi oleh faktor pendidikan yaitu bimbingan yang diberikan seorang terhadap perkembangan orang lain sehingga seseorang tersebut menjadi tahu.Selain itu,dapat disebabkan karena responden merupakan perempuan dalam usia produktif yaitu 15 sampai 49 tahun. Salah satu faktor yang mempengaruhi pengetahuan adalah umur. Semakin cukup umur tingkat kematangan dan kekuatan individu akan lebih matang dalam berfikir.

Peningkatan pengetahuan ini terjadi karena adanya pemberian informasi, dimana didalamnya terdapat proses belajar. Proses belajar dapat diartikan sebagai proses untuk menambah 
pengetahuan, pemahaman, dan keterampilan yang dapat diperoleh melalui pengalaman atau melakukan studi (proses belajar mengajar). Dengan belajar individu diharapkan mampu menggali apa yang terpendam dalam dirinya dengan mendorong untuk berpikir dan mengembangkan kepribadiannya dengan membebaskan diri dari ketidaktahuannya (Notoatmodjo, 2012)

Asumsi peneliti, Pendidikan kesehatan sangat dibutuhkan guna memberikan edukasi kepada wanita usia subur dalam menjaga kesehatan khususnya pengetahuan tentang flour albus yaitu bagaimana cara mencegah keputihan dan cara kebersihan hygiene genital sehingga dengan pengetahuan yang baik, maka dengan sendirinya wanita usia subur dapat menjaga kesehatan organ genetalia.

\section{KESIMPULAN}

Pengetahuan WUS tentang flour albus sebelum diberikan pendidikan kesehatan di BPM Dewi Suyanti Tahun 2020 mayoritas kurang yaitu sebanyak 6 responden. Pengetahuan WUS tentang flour albus sesudah diberikan pendidikan kesehatan di BPM Dewi Suyanti Tahun 2020 mayoritas baik yaitu sebanyak 5 responden. Ada pengaruh yang signifikan antara pendidikan kesehatan terhadap pengetahuan WUS tentang flour albus di BPM Dewi Suyanti Tahun 2020, dengan nilai $p$ $(0,004)<\alpha(0,05)$. Hasil ini membuktikan bahwa pendidikan kesehatan dapat memberikan pengaruh yang baik terhadap peningkatan pengetahuan WUS tentang flour albus di BPM Dewi Suyanti Tahun 2020.

\section{REFERENCES}

Aulia. 2017. Kupas Tuntas Menstruasi Dari A Sampai Z, Yogyakarta: Millestone.

Bobak, I. M. Dkk. 2017. Buku Ajar Keperawatan Maternitas (terjemahan, edisi. 4), Jakarta: EGC.

Darvill, W. Dkk. 2016. The Puberty Book panduan untuk remaja. Jakarta : PT. Gramadia Pustaka Utama.

Hasbullah, 2017., Belajar Mudah Penelitian untuk Guru, Karyawan dan Peneliti Pemula. Bandung: Alfabeta.

Hasbullah,2017., Belajar Mudah Penelitian untuk Guru, Karyawan dan Peneliti Pemula. Bandung: Alfabeta.

Jones, D. L. 2017. Setiap Wanita. Jakarta: PT. Delapratasa Publisihing

Kartono, K. (2016). Psikologi Wanita: Mengenal Gadis Remaja dan Wanita Dewasa. Bandung: Mandar Maju.

Prastika, D. 2016. Hubungan Indeks Massa Tubuh (IMT) Dengan Usia Menarche Pada Remaja Putri. (online), http://azizahmentariindah.blogspot.com/2 013/06/hubungan-indeksmassa-tubuhimtdengan.html, diakses 12 maret 2015.

Purwoko,2017., Perilaku Hidup Bersih Dan Sehat (PHBS). Nuha Medika. Yogyakarta

Mubarak, 2016., Psikologi Anak Dan Remaja. Jakarta: Balai Pustaka

Manuaba, dkk. 2017. Pengantar Kuliah Obstetri. Jakarta: EGC.

Mansur \& Budiarti,2017, Hubungan Dengan Kebiasaan Mencuci Tangan Dengan Kejadian Diare Pada Anak. Diakses Tanggal 02 Oktober, 2017

Maulana, 2017, Pengaruh Perilaku Cuci Tangan Terhadap Kejadian Diare Pada Siswa SD Negeri Magelang. Magelang. Diakses Tanggal 02 Oktober, 2017

Notoatmodjo, S. 2017. Promosi Kesehatan. Jakarta: Rineka Cipta.

Notoatmodjo, 2017., Tentang Persyaratan Kesehatan Perumahan. Jakarta

Notoatmodjo, 2018., Meningkatkan Kualitas Hidup Wanita Menopause, Medika, Vol. 1, pp. 33-38

Proverawati, M. 2017. Menarche, Menstruasi Penuh Makna. Yogyakarta : Nuha Medika

Pulungan, F. (2016). Pengaruh Fungsi Keluarga Terhadap Pemahaman Remaja Putri Usia Sekolah Dasar Tentang Menarche (online). Di akses dari http://repository.usu.ac.id/bits tream/123456789/34639/5/Ch apter\%20I.pdf tanggal 26 maret 2015

Sarwono,2016, Pengaruh Pendidikan Kesehatan Terhadap Pengetahuan Dan Sikap Cuci Tangan Pakai Sabun Pada Sisiwa SD Negeri 157 Kota Palembang Tahun 2014. Artikel Ilmiah

Santrock, 2016, Kata Dokter, Sehat Setiap Hari Ala @ Blogerdokter. Jakarta. Panda Media Wiknjosastro H, Dkk. 2017. Ilmu Kandungan. Jakarta: Yayasan Bina Pustaka 